4. Кочерга О. Розвиток психологічної компетентності вчителя початкової школи / Олександр Кочерга // Рідна школа. - 2013. - № 11. - С. 52-53. 5. Макаренко А. С.Собрание соченений: В 7-ми томах / А. С. Макаренко. - М.: Изд-во АПН РФСР, 1957.- Т. 4. Лекции о воспитании детей. - С. 59. 6. Малихін О. В. Організація самостійної навчальної діяльності студентів вищих педагогічних навчальних закладів: теоретико-методологічний аспект: [монографія] / Олександр Володимирович Малихін. - Кривий Ріг : Видавничий дім, 2009. - 307 с. 7. Мейерс Ч. Кооперативные студенческие проекты / Ч. Мейерс, Т. Джонс// Метод проектов в университетском образовании; под общ. ред. М. А. Гусаковского. - Минск: БГУ, 2008. C. 80-96. 8. Національна доктрина розвитку освіти України. - Інфордиск «Законодавство України». - 2007. - № 2. 9. Пошкуратова Т. Практична підготовка студентів - одне 3 найголовніших завдань педагогічної освіти / Тамара Пошкуратова // Початкова школа. - 2013. - № 10. - С. 47-50. 10. Пускаева Т. Д. Современные модели кооперированного обучения: методики США / Т. Д. Пускаева// Химия в школе.1993. - № 3. - C. 43-45.

\title{
ДО ПИТАННЯ ПРО ВПЛИВ ПРОФЕСІЙНОЇ САМООРГАНІЗАЦЇ̈ НА ФОРМУВАННЯ ПЕДАГОГІЧНОГО ПРОФЕСІОНАЛІЗМУ МАЙБУТНІХ УЧИТЕЛІВ
}

Дуднік Н. Ю. До питання про вплив професійної самоорганізації на формування педагогічного професіоналізму майбутніх учителів.

У статті розглянуто деякі теоретичні підходи щодо визначення поняття «педагогічний професіоналізм». Проаналізовано вплив професійної самоорганізації на розвиток професіоналізму майбутніх учителів. Порівняно зміст понять «професійна самоорганізація» та «самоорганізація професійної діяльності».

Ключові слова: педагогічний професіоналізм, професійна самоорганізація, самоорганізація професійної діяльності, майбутні вчителі.

Дудник Н. Ю. К вопросу о влиянии профессиональной самоорганизации на формирование педагогического профессионализма будущих учителей.

В статье рассматриваются некоторые теоретические подходы к определению понятия «педагогический профессионализм». Проанализировано влияние профессиональной самоорганизации на развитие профессионализма будущих учителей. Проведено сравнение содержания понятий «профессиональная самоорганизация» и «самоорганизация профессиональной деятельности».

Ключевые слова:педагогический профессионализм, профессиональная самоорганизация, самоорганизация профессиональной деятельности, будущие учителя.

Dudnik N. Yu. The effect of the professional self-organization on the formation of professional pedagogical professionalism of future teachers.

The article considers some theoretical approaches to defining the notion of «pedagogical professionalism». It also provides the influence of professional selforganization on the development of future teachers' professionalism. The comparison of content of such concepts as «professional self-organization» and «self-organization of professional activity» is given.

Key words:pedagogical professionalism, professional self-organization, self- 
organization of professional activity, future teachers.

В умовах соціально-економічних перетворень у суспільстві, коли кардинально перебудовується вся сукупність суспільних відносин, з-поміж стратегічних напрямів модернізації національної системи освіти одним 3 актуальних постає завдання професійної підготовки педагогічних кадрів, на які покладено провідну роль у навчанні та вихованні нових поколінь.

Проблема педагогічного професіоналізму - складна i багатоаспектна залишається серед найактуальніших, таких, що завжди зацікавлено обговорюються в наукових колах. Різні аспекти формування професіоналізму майбутніх фахівців розглядаються у філософії, соціології, психології, педагогіці, акмеології та інших гуманітарних і прикладних науках. Такий цілісний підхід дослідження проблеми продиктовано потребою вчителя-професіонала в сучасній школі.

Значний внесок у розроблення теоретичних основ педагогічного професіоналізму зробили Є. Климов, Н. Кузьміна, К. Платонов, В. Сластьонін, В. Сухомлинський, О. Щербаков та інші. Дослідженням індивідуальних характеристик професійного обличчя вчителя опікувалися Ф. Гоноболін, В. КанКалик, Л. Кондрашова, 3. Курлянд, О. Мороз, М. Ярмаченко та ін.; питання професійної підготовки і діяльності фахівців вивчали О. Абдулліна, Г. Балл, В. Галузинський, М. Євтух, Н. Кічук, Л. Нечепоренко, Н. Ничкало та ін.

Метою статті є вивчення впливу професійної самоорганізації на розвиток педагогічного професіоналізму майбутніх учителів.

У сучасних українських розвідках існує декілька суттєвих визначень професіоналізму, серед яких провідним $є$ його тлумачення як достатній для творчого розв'язання задач професійної діяльності рівень розвитку професійної культури і самосвідомості особистості [3].

Водночас I. Підласий та С. Трипольська розглядають професіоналізм як систему набутих упродовж професійного навчання якостей, уміння мислити i діяти професійно. Також заслуговує на увагу запропонована науковцями структура педагогічного професіоналізму. Ії̈ зміст виражено через поняття «ідеального педагога», в особистості якого поєднуються якості фахівця, працівника та просто людини. Відповідно до цього положення автори визначають професійні риси педагога-професіонала: фізичне здоров'я та високу працездатність; урівноваженість психічних процесів; спокійний характер та стійку (розвинуту) волю; ініціативність; організаційні здібності і навички; високий рівень загальної освіти і належну фахову підготовку; прагнення до самовдосконалення i поповнення своїх знань; знання споріднених наук про людину; знання методики викладання предметів; знання останніх досягнень науки; розуміння учнів; уміння спілкуватися 3 ними; володіння сучасними технологіями навчання і виховання; дисциплінованість і відповідальність; суспільна активність [9]. Саме сформованість у майбутнього вчителя вищезазначених якостей свідчить про рівень його педагогічного професіоналізму.

Дещо іншої точки зору щодо структури педагогічного професіоналізму дотримується Н. Гузій, яка розробила власну модельну конструкцію досліджуваного феномену. Педагогічний професіоналізм, на думку науковця, слід визначати цілісністю особистісних та діяльнісних виявів феномену як органічно взаємозалежних підсистем, а його концептуальну схему- єдністю професіоналізму педагогічної діяльності та професіоналізму особистості педагога як базових складників [3].

Більш грунтовними і переконливими $є$ думки науковців, які вважають, що педагогічний професіоналізм необхідно розглядати ширше, ніж сукупність 
професійних характеристик та якостей особистості, що відповідають вимогам учительської професії. Так, Л. Кондрашова зазначає, що змістовий бік педагогічного професіоналізму складається не лише 3 професійно значущих якостей особистості педагога, але й з набору певних засобів (інтелектуальних, моральних, духовних), які забезпечують педагогічний уплив вчителя на вихованців [5]. Погоджуючись 3 Л. Кондрашовою, ми вважаємо, що педагогічний професіоналізм потрібно розуміти як комплексну характеристику, системне особистісне утворення, що поєднує в собі професійні знання, уміння, навички, особистісні якості, які відбивають специфіку вчительської праці і засобів, постають сукупною силою розв'язання професійнопедагогічних завдань [10].

Високий рівень педагогічного професіоналізму досягається вчителем лише тоді, коли в нього виникає й реалізується потреба професійного саморозвитку та самовдосконалення, мотиваційно-ціннісного ставлення до себе як до суб'єкта педагогічної діяльності. Останнє виявляється в усвідомленні майбутнім учителем ролі професійної самоорганізації та систематичному застосуванні в педагогічній діяльності уміння цілепокладання, планування, уміння організації та регулювання діяльності, уміння контролю та аналізу результатів власних дій.

Специфіка професії педагога полягає в тому, що досягнення високого рівня професіоналізму тісно пов'язано з особистісним зростанням людини, і становлення вчителя-професіонала можливе лише як результат єдності його професійного та особистісного розвитку.

Для того щоб стати вчителем-професіоналом, студент ще у ВНЗ повинен навчитися раціонально організовувати власну діяльність, виявляючи при цьому активність у самопізнанні власних можливостей, визначенні основних напрямків самовдосконалення, шляхів та методів досягнення поставленої мети, розвитку власної самоорганізації.

У сучасній науковій літературі у зв'язку з розвитком системного та синергетичного підходів питанню самоорганізації особистості приділяється все більше уваги. Самоорганізацію розглядають як діяльність та здатність особистості, що пов'язана 3 умінням організовувати себе i виявляється в цілеспрямованості, активності, обгрунтованості, мотивації, плануванні своєї діяльності, швидкому прийнятті рішень і відповідальності за них, критичності в оцінюванні результатів своїх дій, почутті обов'язку [1, с. 231]; цілеспрямований процес, під час якого створюється, відтворюється або вдосконалюється організація складної динамічної системи [1, с. 305].

М. Аверін, Т. Авєріна, Ю. Болотін [6] пропонують більш глибоке визначення самоорганізації, розуміючи іï як біологічну та соціальну характеристику людини: 3 одного боку - це вроджена атрибутивна здатність усіх біологічних систем самостійно підтримувати, відроджувати та вдосконалювати рівень своєї організації при зміні зовнішніх і внутрішніх умов існування і діяльності з урахуванням набутого раніше досвіду задля збереження цілісної системи, підвищення ії стійкості і забезпечення нормального функціонування й розвитку; 3 іншого, - цілісний спосіб життя особистості, ii усвідомлена навчально-виховна i розвивальна самодіяльність, спрямована на всебічний розвиток власних сил, постійне вдосконалення якостей, здібностей та вмінь, необхідних у житті, навчанні, праці [6, с. 54].

На думку С. Амірова та В. Мосолова, самоорганізація - це свідома робота над собою задля вдосконалення емоційних та морально-вольових рис характеру в діяльності, яка спрямована на розвиток і розв'язання суспільних особистісно значущих завдань [11, с. 50].

У якості діяльнісного утворення самоорганізація вперше розглядається в роботах 
К. Варшавського та М. Мурачковського [2; 7], які пропонують розуміти їі як систему вмінь або як комплекс заходів, які здійснює робітник для забезпечення систематичності та впорядкованості власної діяльності.

Різноманітність визначень поняття «самоорганізація» свідчить про складність досліджуваного явища. Аналіз наведених вище даних дозволяє зробити висновок про те, що самоорганізація - цілеспрямована діяльність особистості з метою накопичення певної інформації, її узагальнення, аналізу, формулювання висновків та визначення шляхів подальшого самовдосконалення особистості.

Відсутність навичок самоорганізації заважає людині розкрити багатогранність своїх індивідуальних особливостей, ефективно розвивати психічні процеси та набувати професійного досвіду, не надає можливості самореалізації та самовдосконалення.

Частіше за все самоорганізацію розглядають 3 точки зору іiі важливості для розвитку певних вольових, моральних, інтелектуальних якостей особистості. У той же час майже нерозкритим залишається питання впливу самоорганізації особистості на розвиток професіоналізму фахівця.

Професійна самоорганізація важлива для фахівців будь-якої сфери діяльності. Для майбутніх учителів особливого значення набуває педагогічна самоорганізація.

Ми поділяємо позицію Т. Новаченко, яка пропонує розглядати педагогічну самоорганізацію як цілісне, динамічне утворення особистості,що характеризується сукупністю педагогічної рефлексії, професійної компетентності та самоуправління і спрямоване на безперервне самовдосконалення для здійснення якісної професійної діяльності [8, с. 249].

Ці компоненти педагогічної самоорганізації тісно взаємопов'язані, взаємодіють та взаємозалежать одне від одного, утворюючи складну систему, яка має чітку функціональну структуру.

Аналіз структурних компонентів педагогічної самоорганізації дозволяє зробити висновок про те, що професійна самоорганізація - це складне системне утворення, яке можна розглядати як умову, процес та результат особистісного вдосконалення майбутнього вчителя. Але тільки оволодіння майбутнім фахівцем кожним із компонентів складної структури самоорганізації забезпечить очікуваний високий результат професійного та особистісного розвитку.

Дослідження питання взаємозв'язку між розвитком самоорганізації особистості фахівця та ефективністю його професійної діяльності показало, що поняття професійної самоорганізації та самоорганізації професійної діяльності часто ототожнюються. На нашу думку, ці поняття взаємопов'язані, але не замінюють одне одного, оскільки мають різне змістове наповнення.

Поняття «самоорганізація особистості» має два основних значення. 3 одного боку, його можна розглядати як особливу характеристику людини як відкритої системи, здатної до активної взаємодії із зовнішнім світом та до саморозвитку, 3 іншого,- це безпосередньо активна цілеспрямована діяльність особистості задля власного самовдосконалення та самореалізації.

Порівнюючи зміст понять «професійна самоорганізація» та «самоорганізація професійної діяльності», можна зробити висновок, що перше поняття значно ширше, адже воно охоплює обидва сутнісні значення самоорганізації- i особистісне (характерологічне), і діяльнісне. Отже, поняття професійної самоорганізації також можна розглядати в двох аспектах: по-перше, як самостійну організацію власної діяльності на високому професійному рівні, тобто якісне самостійне виконання певних завдань завдяки сформованості вмінь та навичок організатора-професіонала; 
по-друге, як особливу характеристику особистості, яка зумовлює ii системну цілісність, активність у професійному становленні, саморозвитку, професійному самовдосконаленні та прагнення до професійної самореалізації.

Поняття «самоорганізація професійної діяльності» розглядаються в нашому дослідженні як цілеспрямована діяльність особистості, зорієнтована на оволодіння необхідною інформацією, іiї оброблення, узагальнення та аналіз із метою ефективного виконання своїх професійних зобов’язань.

Такий підхід до розуміння поняття самоорганізації професійної діяльності дозволяє зробити висновок про те, що воно є структурним складником діяльнісного компонента більш широкого поняття професійної самоорганізації особистості.

У нашому дослідженні самоорганізація розглядається як специфічна характеристика особистості майбутнього вчителя, результат та умова активності студентів у професійній самореалізації та самовдосконаленні.

Отже, для досягнення позитивних результатів у будь-якій діяльності (зокрема для реалізації проекту розвитку власної особистості) потрібна активна робота самої людини, спрямована на оволодіння відповідними вміннями: умінням визначати цілі, планувати процес їх досягнення, приймати рішення, організовувати власну діяльність для здійснення поставленої мети, контролювати цей процес та оцінювати отримані результати.

Усвідомлення майбутніми вчителями власного професійного обличчя, активне прагнення студентів до професійної самореалізації, сформованість умінь професійної самоорганізації $є$ необхідними складниками професіоналізму майбутніх учителів.

\section{Література}

1. Большой энциклопедический словарь : в 2 т. / [гл. ред. Прохоров А. М.]. - М. : Советская энциклопедия. - Т. 2. - 1991. - 768 с. 2. Варшавский К. М. Организация труда научных работников / К. М. Варшавский. - М. : Экономика, 1975. - 109 с. 3. Гузій Н. В.Основи педагогічного професіоналізму: [навч. посіб.] / Наталія Василівна Гузій. - К.: НПУ ім. М. П. Драгоманова, 2004. - 156 с. 4. Зязюн І. А. Краса педагогічної дії:[навч. посіб.] / І. А. Зязюн, Г. М. Сагач. - К. : Українсько-фінський інститут менеджменту i бізнесу, 1997. - 302 с. 5. Кондрашова Л. В. Методика подготовки будущего учителя к педагогическому взаимодействию с учащимися/ Л. В. Кондрашова. - М. : Изд-во «Прометей» МГПИ им. В. И. Ленина, 1990. - 160 с. 6. Концепція самоорганізації розвитку особистості учня у навчально-виховному процесі / М. О. Авєрін, Т. А. Авєріна, Ю. П. Болотін, Є. С. Львов, Л. С. Філоненко // Рідна школа. - 1993. - № 8 - С. 53-60. 7. Мурачковский Н. И. Как предупредить неуспеваемость школьников / Н. И. Мурачковский. - Мн. : Нар. асвета, 1977. - 80 с. 8. Новаченко Т. Педагогічна самоорганізація в післядипломній освіті педагогічних працівників / Т. Новаченко // Гуманітарний вісник ДВНЗ «Переяслав-Хмельницький державний педагогічний університет ім. Г. Сковороди»: Науково-теоретичний збірник. - Переяслав-Хмельницький, 2007. - С. 248-251. 9. Підласий І. Формування професійного потенціалу як мета підготовки вчителя / I. Підласий, С. Трипольська // Рідна школа. - 1998. - №1.- С. 3-9. 10. Професійне становлення майбутнього вчителя: монографічний огляд /за ред. Л. В. Кондрашової. - Кривий Ріг, 2006. - 327 с. 11. Самоорганизация личности в процессе обучения / С. С. Амиров, В. М. Мосолов, Г. П. Сечина, Н. И. Сухорукова // Педагогика. - 1993. - № 5. - С. 49-52. 